\title{
CLAREAMENTO DENTAL: UMA ALTERNATIVA ESTÉTICA E CONSERVADORA
}

Edmara Tatiely Pedroso BERGAMO, Aline Akemi MORI, Gabriela Cristina SANTIN, Guilherme BOSELLI, Renata Correa PASCOTTO

Em odontologia estética, a cor dos dentes é muito valorizada. A indicação e eficiência do procedimento clareador dependerão da causa do escurecimento. Considerando que o sucesso do tratamento clareador depende de um correto diagnóstico da alteração de cor, bem como da técnica empregada, o objetivo deste trabalho é apresentar e discutir a etiologia das descolorações bem como a efetividade das técnicas atualmente empregadas para o clareamento de dentes vitalizados, salientando os principais riscos e cuidados a serem tomados durante o procedimento. Para isso, será apresentado um caso clínico, demonstrando a técnica de clareamento no consultório, com o uso do peróxido de hidrogênio a 35\% (Whiteness HP, FGM), após o isolamento absoluto do campo operatório. Após a realização de 2 sessões de tratamento, realizando-se a aplicação do gel clareador 3 vezes em cada sessão, durante 10 minutos, sem nenhuma ativação física do produto, observou-se um clareamento satisfatório, notando-se a mudança de cor dos dentes, segundo a escala Vita, de A3 para A1. Concluiu-se que desde que se realize um correto diagnóstico da alteração de cor e empregue-se a técnica seguindo todos os passos recomendados pelo fabricante, o clareamento apresenta-se seguro e viável como alternativa estética e conservadora para dentes escurecidos. 